\title{
THE POPULAR DA'WAH MOVEMENT IN URBAN COMMUNITIES: THE ROLE OF HADRAMI SCHOLARS' DA'WAH IN RESPONSE TO RELIGIOUS RADICALISM IN INDONESIA
}

\begin{tabular}{c} 
Arif Zamhari \\
Syarif Hidayatulah State Islamic University Jakarta \\
Cempaka Putih, East Ciputat, South Tangerang, Banten, Indonesia, 15412 \\
E-mail: arif.zamhari@uinjkt.ac.id \\
Imam Mustofa \\
State Islamic Institute Metro \\
Iringmulyo, Metro, Lampung, Indonesia, 34112 \\
E-mail: mustofaiain@metrouniv.ac.id \\
\hline \multicolumn{2}{c}{ Revised: } \\
\hline Received: \\
$\mathbf{1 8 / 0 3 / 2 0 2 0}$
\end{tabular}

DOI: https:/ / doi.org/10.32332/akademika.v25i1.2385

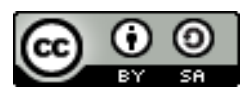

The Popular Da' wah Movement In Urban Communities: The Role Of Hadrami Scholars' Da' wah In Response To Religious Radicalism In Indonesia Life Licensed Under a Creative Commons Attribution-

ShareAlike 4.0 International License

\begin{abstract}
This article discusses how the role of the scholars of the descendants of Hadrami or known as Habib performs the activities of popular Islamic Preaching (henceforth: da'wah) in the urban community. This paper specifically analyzes the activities of da'wah of Majelis Salawat Ahbabul Mustafa led by Habib Syech, a Habib, a descendant of the Prophet who lived in Solo, Central Java. Recently, a similar da'wah was made by young Habib to gain popularity among the youth in several major cities in Indonesia. By using the media of tambourine instrumental music in reading the Shalawat, the da'wah of Habib Syech successfully attracts the interest of many participants who mostly came from groups of young people. In the middle of the hard blasphemies of the Salafi Preacher (Dai) against the majority of the religious practices of Indonesian Muslims, the Majelis Salawat led by Habib Shaykh conducted the 'counter attack' by means of-ways and elegant manners. This group also performs the da'wah through a cultural approach as Walisongo did
\end{abstract}


by using Javanese idioms to get closer to the objects of da'wah which are mostly located in Java.

Keywords: Habib, Majelis Salawat, Da'wah, Youth.

\section{A. Introduction}

In recent decades, the movement of puritanism transnational Islamic revival has grown widely in the Southeast Asian region. The puritanism $d a^{\prime} w a h$ movement does not only widely influence in rural communities but also among the people of the urban middle class. Recently, the da'wah movement has been widely grown among the urban middle class. Of course, this puritanism $d a^{\prime} w a h$ directly affects the practices of religiosity for the majority of Muslims in Indonesia. As a result, they often adopt the symbols of Arab culture as a means to affirm their commitment to the implementation of the 'true' Islam. One of the biggest driving forces of the movement of Arabization among Muslims in this region is the movements of Salafi and Wahabi who get financial supports from Saudi Arabia ${ }^{1}$. Since its presence in Nusantara, these movements are very hostile to the religious practices which have long been grown in Nusantara such as the tradition of the tarekat (Sufism), the Majelis Dzikir and Salawat, the reading of the maulid of the Prophet, as well as the religious traditions of other Muslims that are considered as a statement of heresy (bid'ah) and superstition (khurafat) $)^{2}$.

However, in the last decade, there are symptoms of the 'fightback' from the majority of Muslims of Nusantara against the efforts among the Salafi advocates who often denigrate religious and cultural practices of local Muslim communities in Nusantara. The efforts of this resistance appear in the defense of the Muslim scholars (Ulama) against the practices of the religious rituals that they have been doing. Besides, many scholars increasingly assert themselves as defenders and followers of the sunnah and the salaf by affirming that the cultural practices of Islam are according to the teachings of their religion. The Efforts to 'fightback' are not only seen from the efforts of the award of the practices of Tasawuf that has its roots

1 Noorhaidi Hasan, "Ambivalent Doctrines and Conflicts In the Salafi Movement In Indonesia," in Global Salafism, 2014, https:// doi.org/10.1093/acprof:oso/9780199333431.003.0008.

2 Elizabeth Sirriyeh, Sufis and Anti-Sufis: The Defence, Rethinking and Rejection of Sufism in the Modern World, Sufis and Anti-Sufis: The Defence, Rethinking and Rejection of Sufism in the Modern World, 2014, https://doi.org/10.4324/9781315027388. 
from the Qur'an but also the growing popularity of the recitation of Salawat and Dzikr that is strongly opposed by the group of Salafi-Wahabi .

The defenders of the practice of Dzikr and Salawat ritual are among the groups of Muslims who come from a group of Arab Hadrami, descendants of the Prophet, or the so-called Habib, or Sayyid, which traditionally has the roots of tradition with the center of knowledge in Hadramaut, Yemen ${ }^{3}$. Besides the group of Habib, among the indigenous Muslims also do the 'resistance' against the attacks of Salafi-Wahabis toward practices that are associated with the ritual of Salawat and Dzikr they do. The Majelis Dzikr initiated by the Kyai (Muslim Scholars) of the pesantren (Islamic Boarding School) also fights against the Salafists as shown in this paper.

The descendants of Sayyid or often called Habib ${ }^{4}$ actively organize various religious activities in the last decade $^{5}$. The popular religious activity that attracts the interest of tens of thousands of Muslims, especially in urban areas, is the recitation ritual of Salawat and Dzikr in the open field at night accompanied by music and interspersed with lectures on religion (Mau'idhah Hasanah). The Model of religious ritual like this can not be called as a traditional ritual, though their rituals have similarities with the practices of Hadrami in Indonesia and the ritual practices that occur in the cultural circles of traditional Islam in Nusantara (Pesantren or the community that has the proximity to Pesantren). In contrast, the practice of large religious rituals by collecting a large number of people becomes a new religious ritual phenomenon that has never been before. Unlike other rituals (Sekatenan or Haul among the family of Hadrami), this kind of activity is announced to the public. Majelis Dzikr and Salawat regularly inform the activity to their followers by utilizing modern communication products such as the internet, Facebook, Whatsapp, and Twitter ${ }^{6}$.

This paper aims to see how the role of scholars of Hadrami in doing popular $d a^{\prime} w a h$ movement in the urban community. In particular, this

3 Syamsul Rijal, "Revitalizing Hadhrami Authority: New Networks, Figures and Institutions among Habā'ib in Indonesia," Studia Islamika 27, no. 20 (2020): 239-72.

4 Frode $\mathrm{F}$ Jacobsen, Hadrami Arabs in Present-Day Indonesia (London: Routledge Taylor\& Francis Group, 2009).

${ }^{5}$ Serge D. Elie, "The Graves of Tarim: Genealogy and Mobility across the Indian Ocean - By Ho, Engseng," Journal of the Royal Anthropological Institute, 2010, https://doi.org/10.1111/j.1467-9655.2009.01604_10.x.

${ }^{6}$ A. Zamhari and J.D. Howell, "Taking Sufism to the Streets: Majelis Zikir and Majelis Salawat as New Venues for Popular Islamic Piety in Indonesia," RIMA: Review of Indonesian and Malaysian Affairs 46, no. 2 (2012). 
article also aims to view how the strategy of $d a^{\prime}$ wah is carried out by Habib in facing the 'attack' of the da'wah movement by urban Muslim puritanism. This paper originates from a brief research with the approach of digital ethnography. This research is carried out by conducting an interview and a review of several online sources about the way of Habib Syech and his Majelis Salawat in doing da'wah through the recitation of the Salawat. This research is also conducted by recording some groups of social media that relate to Habib Syech and his group of Salawat?.

\section{B. Theoretical Considerations}

This paper aims to conduct a comprehensive investigation on the practice of $d a^{\prime} w a h$ which is packed with rituals of Salawat and the mass mobilization that attract thousands of followers of all ages, from adolescents to older people. This kind of religious ritual is made in the form of a recitation of Salawat and Dzikr which is sung with the accompaniment of tambourine musical instruments (Tambourine, Hadrah, Terbang, Marawis) led by Habaib (the plural form of Habib). The presence of Islamic religious rituals in the form of mass rallies politically and culturally is very significant because it serves as a place to declare personal awareness (self - consciousness), an alternative to the movement of Islamists, and the movement of transnational religious renewal that propose to return to Islam rigidly. Since the beginning, these movements consider themselves as the only alternative for the religious life and the state in Indonesia.

Besides the ritual of Salawat and Dzikr led by Habaib, the such practice of the ritual of Salawat and Dzikr has also grown rapidly in Nusantara in the last two decades especially with the large numbers of the group of Dzikr which have links with several Pesantren in Java. Unlike from the ritual practices of Salawat and Dzikr that had developed in the Muslim communities in Indonesia before, the rise of this ritual in some regions is placed in an organization called the Majelis Dzikr and Salawat 8. It is important to know that the study of Majelis Dzikr is quite rare, especially in the study of the Islamic ritual practices in Nusantara. In contrast to the abundance of studies on groups of the tarekat (Sufi orders), only a few

${ }^{7}$ Julia Day Howell, "Revival Ritual and the Mobilization of Late-Modern Islamic Selves," Journal of Religious and Political Practice, 2015, https://doi.org/10.1080/20566093.2015.1047691.

8 Arif Zamhari, Rituals of Islamic Spirituality: A Study Of Majlis Dhikir Groups In East Java, 1st Editio (Canberra: ANU Press, 2010). 
researchers in and outside the country who comprehensively examine the development of Majelis Dzikr in the context of Islam in Nusantara.

The lack of research about the group of Salawat in Nusantara is unfortunately often coupled with criticism toward Majelis Salawat and Dzikr by Islamic revivalist groups (Salafis group), and other Islamist groups in Nusantara. For the revivalists, this Majelis is considered as a deviation (bid'ah) of Islam because the practices of the Salawat and Dzikr do not have a strong foundation in the teachings of Islam. Moreover, Islamic revivalists consider the rituals and teachings of Majelis Salawat are interfered with by powerful local elements which are contrary to the teachings of the Qur'an and the Sunnah. In addition, among the Islamic revivalist also consider the ways of the rituals of Dzikr and reciting the Salawat with the sound that is practiced by the Majelis Dzikr are contrary to the teachings of Islam because the Prophet Muhammad never did similar ways in doing Dzikr.

Understanding the growth of the Majelis Dzikr and Salawat ritual in Nusantara becomes more important particularly in the context of Islamic preaching in Nusantara. It is undoubtedly that Majelis Salawat and Dzikr has successfully attracted many followers from various social circles. Thus, it means that these groups of Dzikr have contributed significantly to the increase of religious practices among Muslims in Nusantara, particularly among communities that were previously less obedient in the implementation of the teachings of Islam (nominal Muslim). Based on the understanding of the teachings of Islamic Sufism, instead of refusing the communities that belong to this category (nominal Muslims), these Majelis Salawat constitutes showing high respect and accommodation toward the forms and cultural symbols that are familiar among the group of nominal Muslims in Nusantara. Through this way, in the landscape of Islam in Nusantara, Majelis Salawat and Dzikr have contributed to the reduction of the gap (narrowing the gap) between the groups of Santri and nominal Muslims (abangan) in Nusantara, which for a long time, ideologically contrasted ${ }^{9}$. Thus, the study of religious rituals on the Majelis Salawat can also see how far the improvement of practices and spiritual life happens among the Muslim community in Nusantara.

Besides, the research about the ritual of the Majelis Salawat in Nusantara can also equip a comprehensive overview of the rise of Islam and the Muslim communities in Nusantara over the last three decades. All this time, the revival of Islam in the Archipelago is only seen mainly from the forms of the increase of outer expression from the practices of Islamic

9 Clifford Geertz, Religion as a Cultural System." In The Interpretation of Cultures, Selected Essays by Clifford Geertz (New York: Basic Books, 1973). 
teachings implementation like the rising of the people who carry out pilgrimage (hajj), the number of the mosque construction in urban areas, the rampant use of Muslimah fashion, an increasing number of institutions of Islamic philanthropy (Zakat, Infak, and Sadaqah) and sharia banks, the rise of the groups of Islamic spiritual (rohis) at public universities, the rise of the government's sharia law in several regions in Indonesia, and the emergence of Islamic parties and others. Of course, such indicator of the revival of religion in Nusantara is inadequate to view the rise of Islam in Nusantara as a whole. In contrast, the Islamic revival in Nusantara also occurs in the form of the increase of Islamic spiritual (inner Islam) such as the rise of groups of Sufism followers (Tarekat) in Nusantara, the increase of the popularity of the Sufism study in urban areas, and the proliferation of Majelis Salawat and Dzikr in the entire territory of Nusantara ${ }^{10}$. The expression form of Islamic spirituality is as a complement to the Muslims to perform the outward Islamic diversity. Though the practice of Islamic religious rituals in the form of Salawat and Dzikr gets wide media coverage in Indonesia, it rarely gets attention in academic circles in the West who have more interest in the Islamic revival in Indonesia which is very scripturalist. In other words, an overview of the practices of scripturalist's pieties is just one of an overview of the process of the Islamic revival in Nusantara that occurs at the end of the twentieth century, so the serious misunderstanding to see the nature of Islam in Indonesia became inevitable.

The rise of the ritual practices of Salawat and Dzikr as one part of the Islamic revival in the Nusantara has also become a proof that the predictions put forward by Clifford Geertz about the destruction of Sufism are far from the reality. In some of his writings, Geertz predicted, along with economic growth in the modern sectors in some Muslim countries will result not only in the destruction of Sufi groups in those countries but also result in the victory of the group Scripturalist Muslims. The research conducted by Howell (2001) and Zamhari shows that despite having challenges and harsh criticisms that were made by Islamic Salafists, Revivalists, and Reformists, the ritual practices of the Sufism have not only showed rapid growth but also have attracted followers from various social class. In short, not only groups of Tarekat that experience rapid development, but also the Majelis Dzikr and Salawat experience significant growth and successfully attract followers not only from old traditional circles but also from very dynamic teenagers. The interest of the youth in

10 Julia Day Howell, "Sufism and the Indonesian Islamic Revival," The Journal of Asian Studies, 2001, https:/ / doi.org/10.2307/2700107. 
the ritual of Salawat and Dzikr in Nusantara is interesting for further study especially among adolescents who live in urban areas in Nusantara. The urban teenagers who are identical with a party, clubbing, and activities at night become a part of followers and the largest participants in each ritual of Dzikr and Salawat conducted by Habaib around Nusantara.

This paper will update in detail about the study of ethnographic analysis socially and Islamic politics in Nusantara, particularly to track the interaction of the current revival of the transnational with the culture of the indigenous communities as well as identify the mechanisms of social and culture where the ritual of Salawat and Dzikr in the form of mass mobilization is conducted. The process of this research will also look at and document a process called re-alignment between the circles of the Hadrami Arabs with the local communities especially the Muslims of Java.

This paper also has a theoretical contribution which is very important especially in the study of comparative religion and modernization, a theme of sociological study that not only receives less attention in-depth but also is a wide theme of religious study in developing countries ${ }^{11}$. While nearly two decades of the sociological academic study has been devoted to reconceptualize religion in modernity after the deadly criticism against secularization theory, the construction of religiosity that appears at the end of the century is mostly based on data in the European Community and North America. The comparative study on Muslim heritage regions has been caught in a politisiced public discussion centering on the view that the Muslim community is uniquely resistant to the social differentiation that accompanies the process of modernization in other places so that the Muslim community is becoming fully resistant to the formation and maintenance of democracy with religious freedom.

This paper positions itself beyond the sociological analysis of religion and the state as well as the religious pluralism which is the area of comparative analysis of Islamic sociology in the modern era. This study intends to further examine the treasures of the Muslim community called by 12 as 'new religious forms' at the late modernity. This new religious form has the characteristics that emphasize more on religious experiences rather than emphasize the legal aspects in the religion and accommodate the form of the institution of spirituality seeker that is loose and semi-autonomy.

${ }^{11}$ Jose Casanova, Public Religion in the Modern World (Chicago: Chicago University Press, 1994).

12 Yves Lambert, "Religion in Modernity as a New Axial Age: Secularization or New Religious Forms?," Sociology of Religion, 1999, https://doi.org/10.2307/3711939. 
This new religious form also manifests the important figure of the religious leaders and their view of God that is immanent and full of compassion rather than a view of God that is transcendent and creepy. A study conducted by Lambert on 'the new religious forms' in the European community and North America was in line with the religious rituals in the form of mass rallies conducted by the Habaib in Nusantara that emphasize in religious experiences. It is very obvious that not only on the form selection of their rituals that put more emphasis on the importance of the mass rallies in a ritual and specific meaning to that ritual but also on the ritual orchestration as a major performance. Gauthier saw 'performances', the shape of the pilgrimage that was renewed, and religious travel as a symbol of the global diversity of the late modern society. Gauthier saw the tendency to form this kind of religiosity in response to the social pressure and the consumer society's opportunity that were driven by the development of the neo-liberal economy ${ }^{13}$. The same thing happened in Indonesia in the form of new religious spirituality training in the 21st century, such as ESQ Training led by Ary Ginanjar, as a personal means to adapt to the pressure of policies of the post-authoritarian government's neo-liberal economy. Since the beginning of the study on Habaib's Majelis Dzikr and Salawat that performs the ritual of mass marches, it looks clear that they are precisely the opposite. They sought not to be tempted on any occasion to perform the commodification of religion such as in the form of practice 'commercialization of religious training', da'wahtainment through television, aggressive marketing tools of personal da'wah (DVD, SMS text and others) $14 ; 1516 ; 17 ; 18 ; 19$. However, changes in the social life pattern and

${ }^{13}$ François Gauthier and Tuomas Martikainen, Religion in Consumer Society: Brands, Consumers and Markets, Religion in Consumer Society: Brands, Consumers and Markets, 2013, https://doi.org/10.1080/13537903.2015.986995.

14 Daromir Rudnyckyj, "Market Islam in Indonesia," in Islam, Politics, Anthropology, 2010, https://doi.org/10.1002/9781444324402.ch11.

${ }^{15}$ Daromir Rudnyckyj, "Spiritual Economies: Islam and Neoliberalism in Contemporary Indonesia," Cultural Anthropology, 2009, https://doi.org/10.1111/j.1548-1360.2009.00028.x.

16 Noorhaidi Hasan, "The Making of Public Islam: Piety, Agency, and Commodification on the Landscape of the Indonesian Public Sphere," Contemporary Islam, 2009, https://doi.org/10.1007/s11562-009-0096-9.

${ }^{17}$ Greg Fealy and Sally White, Expressing Islam: Religious Life and Politics in Indonesia, Expressing Islam: Religious Life and Politics in Indonesia, 2008.

18 Julia Day Howell, "Modulations of Active Piety: Professors and Televangelists as Promoters of Indonesian 'Sufisme,'" in Expressing Islam: Religious Life and Politics in Indonesia, 2008, https:// doi.org/10.1355/9789812308528-007. 
communication that are driven by the process of the integration of the country into the current network of global production and exchange of information will form the public preferences at least to get in touch with the religious Dai through the ritual of the Salawat and Dzikr that is initiated by Habaib.

\section{A Brief Biography of Habib Syech}

Habib Syech or his full name Habib Syech son of (bin) Adul Qadir son of (bin) Abdurrahman Assegaf is known not only as a Dai of Arab descent but also known as the singer of Salawat which is very popular from Solo, Central Java. His name is not only known throughout the archipelago but also in neighboring countries, such as in Malaysia, Brunei, and Singapore. He was born on the 20th of September 1961 as the first child of sixteen brothers and sisters. He was born of the couple al-Habib Abdul Qadir son of (bin) Abdurrahman and Bustar daughter of (bint) Umar alQaziri. His father was an imam of Assegaf mosque, one of the two mosques that belong to the descendants of Hadrami in Solo. His father died when he was kneeling while being an Imam of Jumah prayer, which adds to his reputation in the community. Habib Syech's education started from one primary School near Pasar Kliwon in Ponorogo, East Java. After graduating from elementary school, Habib Syech continued his education at Al-Islam Junior High School which then continued at the same High School. However, Habib Syech could not complete his high school education due to the economic factors of the family. This lack of economic conditions forced Habib Syech to be a breadwinner to make a living, especially after his father went to Saudi Arabia to seek a fortune in there.

Besides studying at formal education, Habib Syech also studied traditional religious education from his father, which includes lessons of Salawat, advice, spiritual guidance and blessings, and religious studies. Through his father, Habib Syech found the inspiration to continue to perform $d a^{\prime} w a h$ and community service in his community. His father also taught him how to take care of and prosper the mosque. His informal education was also obtained from his uncle, Habib Ahmad bin Abdurrahman Assegaf. Through his uncle who lived in Yemen, Habib Syech learned the character and mental building toward the condition of life that is sometimes filled with diatribe and insults. Another figure who also became a teacher of Habib Syech was Habib Anis bin Alwi al-Habsyi (w.2006), one of the Imam of the Riyadh mosque, the City of Solo, the

19 James. 2008. Hoesterey, "Marketing Morality," in Expressing Islam, ed. Greg Fealy and Sally White (Singapore: ISEAS, 2008). 
holder of the maqam of al-Habsyi, and the grandson of Habib Ali bin Muhammad al-Habsyi, the author of the book of mawlid Simtudduror ${ }^{20}$ that is very famous. Habib Anis is the teacher figure of morals and the science of taste (dhauq) that plays an important role in the life of Habib Syech. During his life, Habib Anis was very famous among the families of the Habib in Nusantara. Even many Habib's Majelis Dzikr and Salawat in Indonesia often request approval to Habib Anis before establishing their Majelis Dzikr. Habib Anis for Habib Syech was the figure who was very close to a young child and was very fond. About Habib Anis, Habib Syech said:

"In a dream when I visited my sister-in-law in Madiun, I was instructed by my father to give the iqamah for 'Ashr prayer. Habib Anis was also there. My father said; "Anis, be the Imam and I would be your congregation".

This dream became a cue for Habib Syech to follow the assembly of Habib Anis in Riyadh mosque. This dream at once became the answer to his confusion while looking for a figure of a role model after his father went to Saudi Arabia (Abidin 2014: 26). The education that was obtained by Habib Syech from his father, his uncle, and Habib Anis was one of the forms of transmission of knowledge and the particular blessing among the family of Hadrami in Indonesia that was conducted in the context of the geneology of Arab descent. Through this way, a descendant of the Hadrami is not only assured having the essence of the descendants of the Prophet Muhammad but also get the scientific and spiritual teachings sanad (a trustworthy relation) from the Habib that is connected directly to the Messenger of Allah. Different from the families of the Habib, the Muslim family in Nusantara, especially the family of NU (Nahdlatul Ulama), obtains the transmission of knowledge only through boarding schools (pesantren). Pesantren is central to the transmission and reproduction of knowledge among Muslims of Nusantara. Some of Hadrami indeed sent their children to pesantren, but getting the teachings from Habib in person is still a priority for the Habib family today in Nusantara.

\section{Da'wah and the Echoes of Salawat}

Habib Syech lives as a $D a^{\prime} i$ from a relatively young age. His $d a^{\prime} w a h$ activities were started from the Islamic lecture and discussion in the city of Solo. Like $D a^{\prime} i$ of other Arab descendants, $d a^{\prime} w a h$ that is done by Habib

20 The full name of this book is Simtudduror Fi Akhbar Mawlid Khairil Basyar wa Ma Lahu min Akhlaq wa Aushaf wa Siyar (The Pearls String of the Story of the Birth of Human beings; Morals, the Nature and History of his Life). 
Syech is by emphasizing the sense of love to the Messenger of Allah and sharing foods while breaking the fast in the month of Ramadan. Before his name was widely known by his Majelis Salawat Ahbabul Mustafa, Habib Syech, along with Habib Muhsin, started the $d a^{\prime} w a h$ activities in his home by doing Dzikr. This Dzikr activity was attended by people from various backgrounds with different professional backgrounds. Even, many drunkard hoodlums sometimes attended that Dzikr activity. Habib Syech has a very positive outlook toward this hoodlum groups as follows:

"Tigers are wild. If they are bothered, they will get mad. Those who can conquer them are only animal tamers. It requires knowledge and tricks. Sorry, as far as I know, those hoodlums are only lack of affection. They need attention. They are considered as the scumbag, whereas trash has its benefit. If it is processed, this waste can be so useful items, right?" (santrinews.com)

On one occasion, Habib Syech disenchanted one of the thugs who usually get drunk and never did prayer. This thug came to Habis Syech's Majelis Dzikr with the smell of liquor in his mouth. Habib Syech never gave any advice to this thug. He just invited this thug to read the Salawat. Once upon a time, the thug asked a sarong to Habib Syech. Habib Syech then gave the sarong to him. The thug felt so happy with the giving of this sarong and he finally prayed. Now, this thug becomes a faithful follower at the Majelis Ahbabul Mustafa.

One of the objectives of the Dzikr is to establish friendship as well as to do community empowerment. Community empowerment is done by assisting members of the Majelis who are poor. The Dzikr activity that is conducted on every Thursday and Sunday night continuously grows and needs an organization so that the mission and vision of the Majelis can be done well. Every Sunday Legi (in Javanese calendar), this Majelis members gather in the Assegaf Mosque, Pasar Kliwon, the place where Habib Syech's father became an Imam. In this mosque, the youth gathered to attend the Islamic lecture. Around the 1980s, the youth around the Pasar Kliwon regularly held a food sharing for breaking the fast in Ramadan. In the early 1990s, the youth of this mosque initiated to share the alms of food not only in the month of Ramadan.

Besides food sharing, the youth also took the initiative to conduct Qur'anic education coaching, Islamic lecture, and other religious activities in some villages. This event has been running for almost eight years without an organization. With the development of activities and the number of Majelis members with the limitations of time and funds, the initiative was raised to confound these activities into an organization. The youth who gather every Sunday Legi in the Assegaf mosque took the 
initiative to establish an organization. Habib Syech, along with Habib Muhsin, then formed an organization called the FOSMIL (Forum Silaturahmi Sunday Legi) on Sunday Legi August 9, 1998. This Forum was founded with the following backgrounds: First, the lack of public's understanding on religious matters so that it is important to avoid them falling into idolatry, breaking the religious law, and the following groups (sects) that its aqidah is questionable; Second, the low of community economic living standard (poverty) around the mosque is very influential toward the mosque prosperity. This poverty, in its turn, often blinds their eyes to the law of God which can lead to apostasy. Therefore, it is important to establish an organization that can handle various problems faced by the community around the mosque. Besides, FOMSIL is also expected to be a $d a^{\prime} w a h$ institution among the community that needs religious teachings. During the first establishment, this organization had about 350 members. In early 2002, the number of organization members was around 1000-1300 members. In 2004, members who came once every 35 days were about 5000 people. From all these 1000 people, they have had a member card (www.fosmil.org and www.fosmil.com).

As an organization, FOSMIL has several divisions that help in realizing the programs of the organization. First, the Division of Education and $D a^{\prime}$ wah has various programs such as channeling the mosque and TPA (Quranic Education School) infrastructure such as microphones, carpets, books, and others; conducting training for Imam to take care of the corpse, carrying out training for the teachers of TPA (Quranic Education School), conducting training of Adzan and Iqamat, as well as computer training. Second, the Division of Social runs several programs, such as providing scholarships, facilitating foster children, providing clean water, holding a cheap market, setting up a playground and reading garden, giving the private course, spraying the dengue mosquitos, and giving aids for natural disasters. Third, the Economic Division has several programs such as granting loans for the agricultural business, creating a savings and loan unit, and opening Islamic pawn. The loan is given to people from various social backgrounds and occupations such as a scavenger, pedicab driver, stall owner, and machine shop owner. This loan is given without interest and guarantee, but it is given only based on mutual trust. Those who succeed in their business are asked to give alms and infaq to the forum. However, for those who attempt to go bankrupt are given the lightness to return their loans under the level of disadvantage. The fourth is the Division of Health that initially conducts a community service by providing free treatment at a certain time, but because patients need to be treated at any time, this division then opens the clinic every day. In 2006, 
the clinic evolved into a hall of treatment. After running about five years, the number of patients who sought a treatment reached 62.500 people and 14,000 of them had a medical card (www.fosmil.org). (www.fosmil.org). Habib Syech's da'wah activity was initially done very simply. Besides working as a merchant, Habib Syech does his da'wah routines. The bankruptcy that he experienced as a merchant did not prevent him from carrying out $d a^{\prime} w a h$ during his very difficult period.

To perform his da'wah, Habib Syech even had to ride the bike to attend the invitation from one village to another. While performing $d a^{\prime} w a h$, Habib Syech usually shares foods to his congregation. The $d a^{\prime} w a h$ that was performed by Habib Syech so far did not attract the interest of many people. Not many people were interested to come to the Majelis that he held. Until one day when Habib Syech's uncle came from Yemen, Habib Ahmad bin Abdurrahman Assegaf, inspired him to change the strategy of da'wah. According to Habib Syech, his uncle gave him a gift of the book, Simtudduror, a book of Salawat that is quite famous not only among the Habaib in Yemen but also among the Muslim communities in Nusantara. The giving of the book of Maulid Simtudduror inspired Habib Syech to bring da'wah by reciting Salawat Simtudduror with the beautiful musical instrument of tambourines and some of the songs which were composed by Walisongo, such as Ilir-Ilir, Turi-Turi Putih, Padang Bulan, and others. This idea led him to train young children to recite Salawat accompanied by tambourine musical instruments. In particular, Habib Syech even brought in a coach from South Borneo to educate young children to play the tambourine and sing the Salawat. This group of young people is who will become the first member of the Majelis Salawat Ahbabul Musthafa (the Lover of the prophet), a group of Salawat that was founded by Habib Syech in 1998.

Habib Syech recognizes that the success of the Walisongo's strategy in spreading Islam in Nusantara was not separated from their cultural strategy by using advice poetry in the local language that was accompanied by gamelan music. According to Habib Syech, the Walisongo never prohibited songs and gamelan music. What they did was just to change the disadvantages in the gamelan into something more beneficial. The choice of Walisongo's song lyrics in the Javanese language was indeed reasonable because the object and the location of Habib Syech's da'wah were mostly in the area of Java. Using the Javanese language and song made Habib Syech's da'wah more acceptable to the public. Different from other Habib in Nusantara, Habib Syech's Javanese language proficiency facilitated people to understand the material of Islamic lectures which he delivered, especially in the areas of Central Java and East Java. Besides, the ability to 
combine between the tradition of Hadhrami and Javanese language and culture was able to attract a larger audience.

Habib Syech's knowledge about Java also allows him to maintain the tradition of the Salawat or Javanese Islamic songs and makes him as one of the key figures in a social movement that emphasizes a unity between Islam and Javanese culture in dealing with the Salafis' religious movements that tried to unplug the cultural roots of local communities with Islam. Habib Syech's Emphasis on the rejection of the religious views of the SalafiWahabi is very thick in each his preaching. In certain limits, Habib Syech still uses polite language in rejecting things that are different from the group of Salafi-Wahabi on general practices performed by Muslims in Nusantara. Meanwhile, the emphasis on the elements of the Javanese culture in preaching also became the right momentum especially in the Palace (Keraton) of Yogyakarta to evoke the spirit of Islamic religion in Keraton. Habib Syech as written by Woodward et.al (2012:124) in collaboration with Sultan Hamengkubuwono $X$ and his younger brother Prince Joyokusumo tried to 'bring Islam back into the palace'. For example, in 2010 on the occasion of 263rd Yogyakarta's Birthday, the Palace of Yogyakarta invited the Salawat Performances with Habib Syech and Majelis Salawat Ahbabul Mustafa that fulfilled the yard of the North palace and City Plaza. In the opening of the Yogyakarta City Birthday event, Sultan gave a speech on the importance of Salawat and the reading of the Qur'an as the culture of the palace. Besides the tradition of the Salawat, the tradition of Khatmil Qur'an (Completing al-Qur'an Recitation) is also often performed in the Palace of Yogyakarta. One of the founders of Majelis Salawat Zikrul Ghafilin and Mantab Quranic Sema'an (reading and memorizing Quran at the same time) from Kediri, KH Jazuli or well-known as Gus Mik, during his life was very close to Sultan Hamengkubuwono X 21.

Even a Majelis Dzikr and Semaan of the Qur'an often held events of Dzikr and the Quranic Sema'an regularly at the Palace. As also noted by a Majelis Salawat based in Kota Gede, this Majelis also organized performances of Salawat in Javanese style in the Palace. Instead of using a white shirt, this group wore the Javanese typical dress with the logo of the royal family in the chest and sang the Salawat songs in the Javanese language by using a manuscript collection of the Royal Palace of Yogyakarta. In 2011, this group collaborated with LESBUMI NU (Nahdlatul Ulama Art and Culture Institute) to hold a wayang (puppet)

21 Zamhari, Rituals of Islamic Spirituality: A Study Of Majlis Dhikir Groups In East Java. 
festival by telling the story that was supposedly written by Sunan Kalijaga. The event was held on the eleventh day before Ramadan and was supported and funded by the Sultan Hamengkubuwono X. This event also was secured by paramilitary groups of Banser NU, which also often secure every event performed by Habib Syech. A social movement, the collaboration among religious capital that is owned by Habib, Nahdliyin, and the Palace of Yogyakarta, was never imagined that it could be done on a decade earlier. This social movement can be seen as a form of Islamization and santrinization (a persuasion to be a Santri) that is different from the movement carried out by the Salafi-Wahabi. Besides, this social movement is also a counterpoint discourse toward the development of the form of Islam formalist that is mainly brought by the Dai of Salafi-Wahabi in urban areas. This social movement as recognized by Habib Syech reminds of the social movements that had been done by Walisongo that were able to Islamize Nusantara through the peace cultural movement without violence.

Majelis Salawat Ahbabul Musthofa is known by the public because some of the Salawat songs are very popular among Muslim communities both in Nusantara and other countries. Some of the Salawat poems and religious songs that are sung by this group are cited from various sources of popular maulid books such as Salawat Badar, Burdah, Al-Barzanji, Maulid Diba', Simtutudduror, Habib Syech, and other Muslims scholars' Salawat composition works as well as taken from Javanese songs that were written by Walisongo. ${ }^{22}$ The ability to combine the Javanese tradition into qasidah style is not owned by other Habib who go through the path of $d a^{\prime} w a h$ like Habib Munzir al-Musawwa (Majlis Rasulullah) and Habib Hasan bin Jakfar Assegaf (Nurul Mustafa) (Zamhari, 2012). Nearly dozens of songs and Salawat that are composed and sung by this group are widely accepted in the community until now. Habib Syech's Salawat songs can be found in the market both in the form of DVD and CD. Unlike other singers and songwriters who were very wroth toward the issue of piracy, Habib Syech does not take issue about the piracy of his CDs and DVDs. Responding to the piracy issue, Habib Syech argues:

'For me, the piracy of CD and DVD is not a problem, if, indeed, through this piracy, they could eat and live. The more it is hijacked, the more people listen to Salawat.'

Different from the previous $d a^{\prime} w a h$, the $d a^{\prime} w a h$ with the Salawat recitation made by Habib Syech can attract thousands of people in one

22 The songs that are usually sung by Habib Syech are; Ya Thayyibah, Bijahi al-Musthafa al-Mukhtar, Allah-Allah, Shalatun bi al-Salami al-Mubin, the Poem of Padang Bulan, the Poem of Tanpo Waton, Nurul Mustafa, Ya gharami 
place. The chant of Salawat recitations and Islamic songs presented by Majelis Salawat Ahbabul Mustafa can take the interests of thousands of people whom most of them are teenage children. According to Habib Syech, this is all because of the blessings of Salawat of the Prophet Muhammad. Habib Syech admits that people gathered because of the call of the Messenger of Allah and not because of him. Even specifically, the lovers of Habib Syech formed a fan club of Habib Syech as Syecher Mania.

The number of Syecher Mania almost reached 76.000 members as mentioned by Habib Syech in one of the interviews with some media. There is no special registration to be a member of Syecher Mania. So this group is very open in terms of its membership system. Anyone can be a member of Syecher Mania. Habib Syech is fully aware that the desire to make this fan club is purely made by the initiative of the congregation of young people themselves. Habib Syech never ordered as well as did not prohibit the making of the fan club. As long as their activities are good, they are not prohibited. Bagi For Habib Syech, their presence in the Salawat assembly is better than letting them attend the immoral place and sing songs that can overlook them from the way of Allah. About the problem of Syecher Mania, Habib Syech said:

'They want to do good thing. It is better to stay at Salawat place than in a place of sin. They should be embraced and humanized to be a good human. I and they want to be good and do good deeds. Passing the path of goodness has a lot of challenges. They may carry out an activity as long as it is positive to remember God and His messenger. My advice to Syecher Mania ... I want the Syechers to be a good example for other youth because they bring the prophet Muhammad's name, not my name. They are not my lovers but the lovers of Rasulullah.'23

However, in particular, Habib Syech regulates rules and ethics that must be followed by the Syecher Mania. For example, Habib Syech does not allow them to mix between men and women when attending the Majelis Salawat. They are not allowed to join for the interests of a particular political party. While attending the Majelis, they are also not allowed to bring the wide flag. The women members of Syecher Mania are forbidden to move members of the body when the Salawat poems are chanted and raise both hands too high while praying. These ethics are obeyed by the Syecher Mania unless the rules of separation between men and women that is not easy to enforce. This separation is possible if the number of people is not too many. However, if the number of audiences reaches tens of

${ }^{23}$ Habib Syech's Interview. 
thousands, it is very difficult to discipline them to not mix with the opposite sex. Nevertheless, the organizing committee and the Majelis still give the warning so that they do not mix with the opposite sex in one Majelis . A lot of criticisms are addressed to Habib Syech especially on the problem of the mixing of men and women in one place. In response to this issue, Habib Syech explained:

'Indeed, many things disputed on the issues of gathering (mixing) between men and women in one place and indeed, Ikhtilath (gathering men and women in one place) is not allowed. I had warned the committee to separate men and women as best as possible. They have put all their efforts but there are still some who are still mixed up in one place. Please be noted, while doing tawaf in Masjidil Haram, men, and women are mixed in one mosque. It is not a problem. Will they commit adultery during tawaf? If they do something immoral during tawaf, that's their own responsibility to God. Are we mistaken? We have reminded them, but we still warn them'. ${ }^{24}$

The existence of Syecher Mania which consists of young people is evidence of how reading Salawat has become a part of teens and young people both in the village and in the city. In particular, Habib Syech gives them advice directly in any event of Salawat or through social media such as Facebook. Though the numbers are very large, according to Habib Syech, Syecher Mania does not intend to set up organizational management in each area.

Concerning political parties, Habib Syech, in particular, also provides a clear guide that the council he leads does not affiliate with any particular political party. However, it is unavoidable, according to Habib Syech, that the image of himself is often installed in one of the large billboards by one particular political party without any permission to Habib Syech in person. In some areas, Habib Syech is also often invited by certain political parties such as PKB (Nation Awakening Party), PPP (Development Union Party). Besides, the area political elites ranging from the regent, the deputy governor until the governor ever invited Habib Syech's Islamic lecture. For example, the Regent of Klaten almost every month carries out Habib Syech's lecture and Salawat. Even the Governor of Central Java from PDIP (Indonesian Democratic Party of Struggle) also invited Habib Syech in events of Islamic lecture and Salawat in the office of the governor. The political elites certainly realize how big the social capital and religious capital that is owned by Habib Syech. In this way, Habis Syech can attract a

${ }^{24}$ The Interview of Habib Syech with TV Al-Hijrah Malaysia 
lot of public sympathies. Therefore, these big social and religious capitals can be the main attraction for the political elite to 'use' Habib Syech in raising the image of their politics. The togetherness between Habib Syech and the elite of the political parties inevitably raises the perception of the assembly followers. Yunus (2014: 91), in this case, wrote three different views of the assembly followers. The first group supports Habib Syech to be adjacent and attend the invitation of the political elite. The reason is because the proximity is reasonable and beneficial to both parties. The second group does not agree with the presence of Habib Syech to attend the invitation of the political elite because it will only benefit the political parties and the political elite. They worry that Habib Syech will only be used as a means of political marketing, the imaging media, and their veiled political campaigns. Besides, they also worry that Habib Syech will be used by the political elite to legitimize their political behavior. The third group is moderate that does not support or reject the proximity of Habib Syech with the political elite. For this group, the most important is that this da'wah can be run as it should and this mission can still stay awake.

On any occasion of his lecture, Habib Syech often reviews the importance of a sense of loving to the Prophet Muhammad, reciting Salawat upon him and uncovering the Prophet Muhammad's moral and physical perfection characteristics. Salawat for Habib Syech is one way to get closer to God and the evidence of love to the Messenger of Allah. If someone wants to get safa'at (intercession) and blessings of the messenger of Allah Peace Be upon Him, then there is no other way but to be closer to him. One way to approach the Messenger of Allah is by reading Salawat. One of the signs of love is to always call a loved one or a lover. According to Habib Syech, if someone claims to love, but he never mentions her name and never makes proud of her, then he is not a true lover. Thus, if a person loves the Messenger of Allah then he will mention his name. For Habib Syech, without mentioning the name and reading the Salawat of the Prophet, then someone's love can not be called pure love. His love is just a fake love according to Habib Syech in one of his talk (Abidin 2015:48). In other words, reading the Salawat, according to Habib Syech, is an intimacy and fondness with Rasulullah Peace Be upon Him. Habib said that the lovers of Salawat and all people who present in a Salawat event have a deep longing to Rasulullah. They recite Salawat solemnly and hope to follow the footsteps of the Messenger of Allah.

For Habib Syech, Salawat is a religious virtue that is highly recommended. This worship is the main worship that will be accepted by God even when in reading it with Riya' (showing off acts of worship). This worship is directly exemplified by God and the angels as stated in the 
Qur'an, 'Allah and His Angels sent their blessings on to the Prophet. Allah says, 'O you who believe send your blessings for the Prophet and greet a tribute to the Prophet' (QS.Al-Ahzab 56).25 This verse is often quoted Habib Syech to refute the opinion of other Muslims who refuse the recitation of Salawat during the celebration of Maulid of the Prophet (Prophet Muhammad's birthday). Habib Syech needs to respond to this problem because of not a few among the Salafi-Wahhabis who denounce the practices of the recitation of Salawat in commemoration of the Maulid of the Prophet Muhammad. Among the critics of Salawat of Maulid said that the reading of Salawat stanzas that are performed in the Maulid commemoration is full of flattery to the Prophet Muhammad excessively. Meanwhile, the exaggerated flattery to the Prophet is prohibited by the Prophet himself. In responding to this problem, Habib Syech said, "the praises to the Prophet Muhammad are allowed because a friend and his wife did it. Praising and flattering the Prophet Muhammad does not mean that the Prophet wants to be praised and extolled. For Habib Syech, without praising, the Prophet Muhammad had already been placed in a laudable place in the sight of God. However, the praise and flattery for the Prophet Muhammad are given because we as people hope to go to heaven and get syafa'at from the Prophet Muhammad later in the day of the judgment. Regarding the refusal of some Islamic groups against the recitation of Salawat, Habib Syech as cited in Abidin (2015) said as follows:

'I'm sure that all people love Salawat. So, when some people are saying that they don't like the Salawat which I usually do, it is because they don't have a place in society so that they made the criticism. If someone does not like or hate the Salawat, this means that he is not the ummah of the Prophet Muhammad. It is the same that he didn't run the commands of Allah and his messenger'

Besides, Habib Syech also believes that anyone who praises the Prophet Muhammad both with a beautiful stanza and a composed Salawat by previous scholars will make the Prophet Muhammad happy and bring syafa'at on the day of resurrection (Abidin 2015: 89).

Besides the theme of Salawat, the other theme of $d a^{\prime} w a h$ is also about the figure of the Prophet. The figure of the Prophet Muhammad is the most perfect human figure that is second to none in this world. According to Habib Syech, the Prophet Muhammad is a human but not the same as the other human. The prophet Muhammad was created by God in its very perfect shape, not only for his physical appearance but also for his spiritual

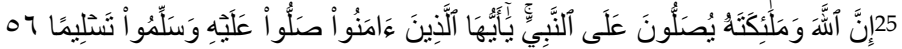


condition. In the creation of the Prophet Muhammad, as if the members of the body of the Prophet that was created by Allah ask Allah to be selected in perfect shape.

Habib Syech's da'wah and Salawat activities now have been increasingly widespread. Majelis Salawat Ahbabul Mustafa regularly conducts the reading of Salawat in some target areas based on the division of the following place: Kenteng Silir and Semanngi (Solo); Kendal-Palm, Donorejo (Sragen); Krajan (Sukoharjo); Gunungan, Melikan (Karanganyar). The allocation of areas in the region of Solo covers: Losari, Jebres; Sragen: Kowang, Mungkung,lemah Ireng, Mbangun Rejo sub-district, Sragen Lor/Ngalorong, Kedungprit, Paldaplang, Made-toho-40 Mekarsari; Karanganyar: Dagen-Garit, Pendem; Sukoharjo: Bakalan, Sangsang, Krtosuro, Transng, and Mayang. The congregations are divided into different areas such as Solo: Kalitan, Clover; Sragen: the As-Sakinah, Macan Mati, Kleco Wetan, Ngadirejo/Kedawung, Tangkil, Plasan, Butuh/Plupuh; Karanganyar: Karang Anom, Jatipuro; Sukoharjo: Ngentak. ${ }^{26}$. The schedule of Habis Syech's lecture is as written by al-Kisah Magazine as follows:

\begin{tabular}{|l|l|l|}
\hline No & \multicolumn{1}{|c|}{ Time } & \multicolumn{1}{c|}{ Place } \\
\hline 1. & $\begin{array}{l}\text { Routine Islamic Teachings of } \\
\text { Wedenesday Night }\end{array}$ & Habib Syech's House \\
\hline 2. & $\begin{array}{l}\text { Selapanan Routine Islamic } \\
\text { Teachings of Friday Night } \\
\text { Kliwon }\end{array}$ & $\begin{array}{l}\text { The Great Mosque of Baitul } \\
\text { Makmur Purwodadi } \\
\text { Grobogan }\end{array}$ \\
\hline 3. & Tuesday Night Pahing & $\begin{array}{l}\text { The Yard of Kudus Great } \\
\text { Mosque }\end{array}$ \\
\hline 4. & Friday Night Legi & $\begin{array}{l}\text { The Yard of Great Mosque of } \\
\text { Baitul Makmur Jepara }\end{array}$ \\
\hline 5. & Saturday Night Pahing & $\begin{array}{l}\text { Assakinah Mosque, Puro Asri, } \\
\text { Sragen }\end{array}$ \\
\hline 6. & Thursday Night Pahing & $\begin{array}{l}\text { The Yard of Minhajuttamyiz } \\
\text { Islamic Boarding School } \\
\text { Timoho, behind UIN Sunan } \\
\text { Kalijaga Yogyakarta }\end{array}$ \\
\hline 7. & Saturday Night Legi & $\begin{array}{l}\text { The yard of Surakarta Great } \\
\text { Mosque }\end{array}$ \\
\hline
\end{tabular}

26 Ahmad Zainal Abidin, Hati Putih Habib Syech: Shalawat, Amalan Dan Inspirasi Hidupnya (Yogyakarta: Saufa, 2014). 


\section{E. The Ritual of Ahbabul Mustafa Salawat Assembly}

Like other rituals of Salawat and Dzikr in common such as in the Capital City of Jakarta, Ahbabul Mustafa's ritual of Salawat also needs a large place and stage with the spotlights and loudspeakers that are commonly used in a music concert. Both the right and left sides of the stage are installed on a large screen that connects to the video camera so that people can watch and participate in this event from a distance. A large stage that was installed on the previous day was prepared for place Habib Syech and guests were specially invited by the organizers of the event. These guests usually consist of local officials, scholars, and community leaders. For example, in an event that organized a large ceremony in Banyumas was attended by Murshid of Tarekat Naqsabandiyah, Shaykh Kabbani from the United States of America, along with his dozens of entourages. This event was also attended by Habib Lutfi bin Yahya, Chairman of the group of Muktabarah al-Nahdliyah Indonesia. Before entering the stage, the guests usually gather at the host event home while waiting for the arrival of Habib Syech. When Habib arrived at the host's residence, Habib Syech was greeted warmly by the host and other guests. They then mingled while enjoying the provided dishes. Then, along with Habib Syech guests, the guests headed to the stage of the event. They sat together on the stage.

Groups of Tambourine instrumental musical players and Salawat reciters usually sit on the stage facing Habib Syech and guests. Their stage position is usually lower than the main stage. These musical players are the members of Ahbabul Mustofa Salawat Group that are brought specifically by Habib Syech in a particular event. The players of tambourine music are also sometimes taken from the local tambourine players. Before the event is started, the Majelis Salawat usually rehearses by trying tambourine tools, microphones, and loudspeakers. They make sure that all tools are good before the performance. People usually come an hour before the event is started. They are recommended to wear white clothes a beloved color symbol of the Prophet Muhammad and a symbol of chastity.

Before the event is officially started, the Majelis Salawat has started with some Salawat poetry recitation while waiting for people gathering at the event venue. People not only come from affiliated organizations such as Nahdlatul Ulama but also the general public from various professional backgrounds. Some of them are some time from the groups of Kejawen. The event is commonly opened by Habib Syech with the recitation of al-Fatehah and the reading of the prayer by asking God and the intercession of the Prophet Muhammad as well as special prayers requested by particular people. Then, Habib Syech started with some of the Salawat Qasida that is 
quite familiar among the public such as Ilir-Ilir, Ya Hananah, and the other qasida songs. The event of this Majelis is almost filled with the reading of Salawat and Islamic songs led by Habib Syech as well interspersed by reading Rawi by a member of the Salawat reader team. Between two Salawat recitation, iti is usually interspersed with the recitation of Dzikr "La ilaha illa Allah" accompanied by tambourine. While following the reading and chanting of praise songs for the Prophet Muhammad, the audiences slightly shook their bodies while lifting their hands to the sky especially in the Salawat song that contains the plea of syafa'at.

Most of the audiences have memorized and followed the recitation of Salawat and the others follow the recitation of Salawat by looking at the maulid book respectively. Some people also raised medium and small flags by following the recitation rhythm of the Salawat. This recitation of Salawat will last almost about an hour. Then the event is continued with tausiah (advice of Islamic values) by Habib Syech and local Muslim scholars. Overall, the recitation ritual of Salawat that are carried out by Majelis Salawat Ahbabul Mustafa will last about three hours. The event usually begins at 20:00 after the evening prayer and ends up at 23:00. Habib Syech never held an event above 23:00 with the consideration that the congregation can wake up early to perform the dawn prayers on time.

In each event of Ahbabul Mustafa's Salawat is always done in a field or mosque with a large courtyard. This group never uses the place such as roads or public facilities that may interfere with the traffic. Habib Syech himself recommends that each event is not done by the closing or covering the highway that may cause traffic congestion or interrupt someone's journey. This is done by Habib Syech to avoid accusations that the practice of Salawat and Dzikr can be a cause of traffic congestion and traffic order disturbance. This practice is different compared to that of Salawat and Dzikir that has been practiced the similar groups in Jakarta such as Majlis Rasulullah and Nurul Mustafa. The latter groups in some occasions hold their ritual by using roads or public facilities that may interfere with the traffic ${ }^{27}$.

\section{F. Conclusion}

This paper discusses the $d a^{\prime}$ wah carried out by Habib in the form of the Salawat group. In particular, this paper discusses how is the strategy of Habib Syaich's da'wah in facing hard criticisms among the Salafis against

27 Arif Zamhari, "Socio-Structural Innovations in Indonesia's Urban Sufism: The Case Study of the Majelis Dzikir and Shalawat Nurul Mustafa," Journal of Indonesian Islam, 2013, https://doi.org/10.15642/JIIS.2013.7.1.119-144. 
the worship practices that are done by the followers of Islam in Indonesia. Besides using public speaking skills, Habib Syaich also utilizes the performance media of Salawat recitation to attract the object of preaching. Habib Syaich does not use many symbols of Habib that emphasize the pattern of Arabs. On the contrary, Habib Syech uses a lot of Javanese symbols in the practice of his da'wah. This strategy is done because the center of the $d a^{\prime}$ wah activity is located in the city of Solo which is known as the cultural center of Java. Besides, the da'wah carried out by Habib Syech is far from the practices of the 'commercialization of religious training', dakwahtainment through television, aggressive marketing tools of personal da'wah.

\section{REFERENCES}

Abidin, Ahmad Zainal. Hati Putih Habib Syech: Shalawat, Amalan Dan Inspirasi Hidupnya. Yogyakarta: Saufa, 2014.

Elie, Serge D. "The Graves of Tarim: Genealogy and Mobility across the Indian Ocean - By Ho, Engseng." Journal of the Royal Anthropological Institute, 2010. https://doi.org/10.1111/j.1467-9655.2009.01604_10.x.

Fealy, Greg, and Sally White. Expressing Islam: Religious Life and Politics in Indonesia. Expressing Islam: Religious Life and Politics in Indonesia, 2008.

Frode $\mathrm{F}$ Jacobsen. Hadrami Arabs in Present-Day Indonesia. London: Routledge Taylor\& Francis Group, 2009.

Gauthier, François, and Tuomas Martikainen. Religion in Consumer Society: Brands, Consumers and Markets. Religion in Consumer Society: Brands, Consumers and Markets, 2013. https:/ / doi.org/10.1080/13537903.2015.986995.

Geertz, Clifford. Religion as a Cultural System." In The Interpretation of Cultures, Selected Essays by Clifford Geertz. New York: Basic Books, 1973.

Hasan, Noorhaidi. "Ambivalent Doctrines and Conflicts In the Salafi Movement In Indonesia." In Global Salafism, 2014. https:// doi.org/10.1093/acprof:oso/9780199333431.003.0008.

- - - "The Making of Public Islam: Piety, Agency, and Commodification on the Landscape of the Indonesian Public Sphere." Contemporary Islam, 2009. https://doi.org/10.1007/s11562-009-0096-9.

Hoesterey, James. 2008. "Marketing Morality." In Expressing Islam, edited by Greg Fealy and Sally White. Singapore: ISEAS, 2008.

Howell, Julia Day. "Modulations of Active Piety: Professors and Televangelists as Promoters of Indonesian 'Sufisme.'" In Expressing 
Islam: Religious Life and Politics in Indonesia, 2008. https://doi.org/10.1355/9789812308528-007.

- - - . "Revival Ritual and the Mobilization of Late-Modern Islamic Selves." Journal of Religious and Political Practice, 2015. https:// doi.org/10.1080/20566093.2015.1047691.

- - - "Sufism and the Indonesian Islamic Revival." The Journal of Asian Studies, 2001. https://doi.org/10.2307/2700107.

Jose Casanova. Public Religion in the Modern World. Chicago: Chicago University Press, 1994.

Lambert, Yves. "Religion in Modernity as a New Axial Age: Secularization or New Religious Forms?" Sociology of Religion, 1999. https:// doi.org/10.2307/3711939.

Rijal, Syamsul. "Revitalizing Hadhrami Authority: New Networks, Figures and Institutions among Ḥabā'ib in Indonesia." Studia Islamika 27, no. 20 (2020): 239-72.

Rudnyckyj, Daromir. "Market Islam in Indonesia." In Islam, Politics, Anthropology, 2010. https://doi.org/10.1002/9781444324402.ch11.

- - - "Spiritual Economies: Islam and Neoliberalism in Contemporary Indonesia." Cultural Anthropology, 2009. https:// doi.org/10.1111/j.1548-1360.2009.00028.x.

Sirriyeh, Elizabeth. Sufis and Anti-Sufis: The Defence, Rethinking and Rejection of Sufism in the Modern World. Sufis and Anti-Sufis: The Defence, Rethinking and Rejection of Sufism in the Modern World, 2014. https://doi.org/10.4324/9781315027388.

Zamhari, A., and J.D. Howell. "Taking Sufism to the Streets: Majelis Zikir and Majelis Salawat as New Venues for Popular Islamic Piety in Indonesia." RIMA: Review of Indonesian and Malaysian Affairs 46, no. 2 (2012).

Zamhari, Arif. Rituals of Islamic Spirituality: A Study Of Majlis Dhikir Groups In East Java. 1st Editio. Canberra: ANU Press, 2010.

- - - "Socio-Structural Innovations in Indonesia's Urban Sufism: The Case Study of the Majelis Dzikir and Shalawat Nurul Mustafa." Journal of Indonesian Islam, 2013. https://doi.org/10.15642/JIIS.2013.7.1.119-144. 